\title{
West Balkan Mineral Register of Primary Raw Materials
}

\author{
Register primarnih mineralnih surovin Zahodnega Balkana \\ Duška ROKAVEC ${ }^{1}$, Matej DRAKSLER ${ }^{1}$, Dejan LEVSTEK ${ }^{2}$ \& Snježana MILETIĆ ${ }^{1}$

\begin{abstract}
${ }^{1}$ Geological Survey of Slovenia, Dimičeva ulica 14, SI-1000 Ljubljana; Slovenia; e-mail: duska.rokavec@geo-zS.si, matej.draksler@geo-zs.si, snjezana.miletic@geo-zs.si,

${ }^{2}$ Avsečeva ulica 17, SI-1000 Ljubljana; Slovenia; e-mail: dejan.levstek@gmail.com
\end{abstract}

Prejeto / Received 3. 3. 2021; Sprejeto / Accepted 1. 7. 2021; Objavljeno na spletu / Published online 19. 7. 2021

Key words: primary raw materials, mineral resources, West Balkan, mineral register, project RESEERVE

Ključne besede: primarne mineralne surovine, Zahodni Balkan, register mineralnih surovin, projekt RESEERVE

\begin{abstract}
Rational and long-term planning and sustainable mineral resources management is of strategic importance in Europe's efforts to secure the self-supply of mineral raw materials. European mineral data is organized and accessible within the pan-European Minerals Intelligence Network. Most EU countries are part of this network, while the West Balkan region presents a gap in this regard. A common West Balkan mineral register needs to be established in order to close the gap and bring the area closer to the EU market. Including the region into the network would provide new opportunities to local industry and improve mineral management at the national and regional level. In this context, the Geological Survey of Slovenia is working in cooperation with numerous partners and stakeholders in different projects within the framework of European initiatives and programs. We collected and properly organized relevant data on minerals in the region according to the INSPIRE Directive. This paper describes the creation of the West Balkan Mineral Register of primary raw materials, and its content.

\section{Izvleček}

Premišljeno in dolgoročno načrtovanje ter trajnostno upravljanje z mineralnimi surovinami je strateškega pomena za surovinsko samooskrbo Evrope. Podatki o evropskih mineralnih surovinah so urejeni in dostopni znotraj vseevropske informacijske mreže o mineralnih surovinah (angl. pan-European Minerals Intelligence Network). Večina držav Evropske unije je že vključenih vanjo, medtem ko predstavlja območje Zahodnega Balkana vrzel v tej mreži. Zato je bilo potrebno izdelati register mineralnih surovin Zahodnega Balkana, ki bo pokril vrzel na tem področju in omenjeno območje približal evropskem trgu. Vključitev regije v informacijsko mrežo bo ustvarila nove priložnosti za lokalno industrijo in hkrati omogočila boljše upravljanje z mineralnimi surovinami tako na nacionalni kot tudi na širši regionalni ravni. S tem namenom izvaja Geološki zavod Slovenije v sodelovanju s številnimi partnerji in deležniki različne projektne aktivnosti v sklopu evropskih pobud in programov. Relevantne podatke o mineralnih surovinah v regiji smo zbrali in primerno uredili v skladu z INSPIRE Direktivo. V članku predstavljamo snovanje Registra primarnih mineralnih surovin Zahodnega Balkana in njegovo vsebino.
\end{abstract}

\section{Introduction}

Europe is aiming to reduce its dependence on imported mineral resources from other continents by increasing its self-supply capacities. One of the most important regions that the European Commission recognizes as a greatpotential contributor to the effort to lower Europe's dependence on imported mineral resources is the South-East Europe (SEE) region and its considerable mineral potential. Southeast Europe, particularly the West Balkans, is rich in primary as well as secondary mineral resources, which are mostly remains of historic or current mining and metallurgical activities. The area has important deposits of copper, lead, zinc, chromium, iron, nickel, and antimony. Furthermore, some explorative geological work is being carried out on new mineral resource deposits (critical raw materials) that are in great demand in Europe. The results of the extensive research work on mineral deposits in the West Balkan are stored in various national archives or have even been lost, which represents a gap in the Europe's existing information system on mineral resources (Fig. 1). Therefore, there was a need for data on primary and secondary mineral deposits in the West Balkans 
region to be systematically collected, interpreted, and arranged in a single place. In addition, such data should be linked to existing European datasets as publicly accessible data, so as the great potential of mineral reserves in the West Balkans makes it a deserving part of the European mineral information platform.

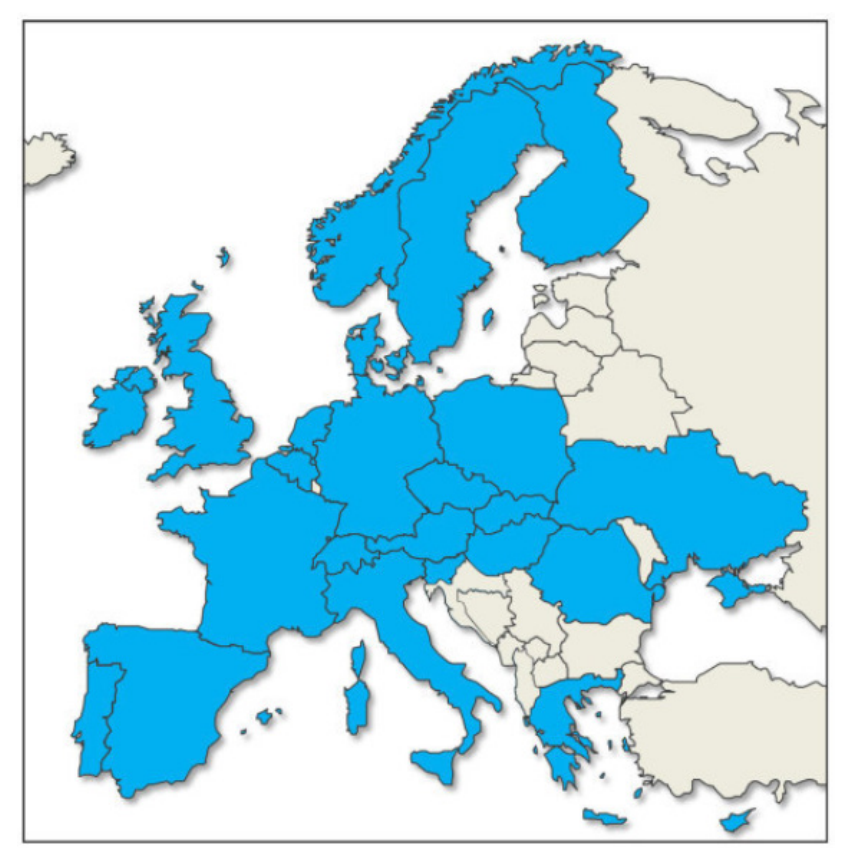

Fig. 1. Data gap (countries in grey) in the Pan European Mineral Intelligence Network (countries in blue) before the RESEERVE project (Archive of the Geological Survey of Slovenia).

Greater collaboration between European and regional partners, as well as with stakeholders is herein of great importance. Owing to the common regional history, knowledge of the local languages, and a good knowledge of the general situation in the area, the Geological Survey of Slovenia can play a significant role in the aforementioned process (Rokavec et al., 2018). Thus, it is intensely involved in the relevant activities and represents a link between EU and West Balkan mineral sector.

\section{Knowledge and Innovation Community (KIC) EIT RawMaterials}

The Knowledge and Innovation Community (KIC) EIT RawMaterials was established in 2014 by the European Institute of Innovation and Technology (EIT). EIT RawMaterials has a vision of a European Union where raw materials constitute a major, strategic strength. Its mission is to grow the European raw materials sector and make it more competitive and attractive through radical innovation and guided entrepreneurship. It is the largest and strongest consortium in the mineral raw materials sector worldwide bringing together 317 European partners from 26 countries and represents all three sides of the knowledge triangle: education, research, and industry. The consortium collaborates in finding new, innovative solutions to secure supply and improve the raw materials sector all along its value chain - from exploration, extraction and processing to recycling and reuse. With innovative technological solutions it strives to ensure the highest degree of EU mineral raw material self-sufficiency possible. EIT RawMaterials has a significant impact on European competitiveness and employment by fostering and driving innovation and empowering entrepreneurs, research, and education institutions to move closer to the circular economy model. This results in the introduction of innovative and sustainable products, processes, and services, as well as expert professionals making European society more economically, environmentally, and socially sustainable (Internet 1).

The Geological Survey of Slovenia is strongly connected to the SEE region through the EIT RawMaterials (RM) knowledge and innovation community as its EIT RM "core" partner. Along with acting as a coordinator or partner in different EIT RawMaterials community projects, the Geological Survey of Slovenia is one of the three cofounders of the Regional Center (RC) Adriahub, together with the Slovenian National Building and Civil Engineering Institute and the University of Zagreb, which connects regional raw materials ecosystems with the EIT RawMaterials community (Draksler et al., 2018).

As a member of the EIT community, the Geological Survey of Slovenia has coordinated two projects with the goal of mapping mineral resources in the West Balkan countries, particularly in Albania, Bosnia and Herzegovina, Croatia, North Macedonia, Montenegro, and Serbia (RESEERVE) (Internet 2) and of creating a dedicated public mining/mineral service (MineService) (Internet 3). Until now, these countries were not included in the existing data platforms that provide raw materials potentials data to interested stakeholders (Fig. 1). The main outcome of such activities is the creation of a West Balkan Mineral Register for primary and secondary mineral resources. The register should serve as a starting point to integrate the region into the pan-European Minerals Intelligence Network and bring it closer to the common mineral market.

Data on West Balkan minerals is now part of the European Geological Data Infrastructure (EGDI) portal and the complete Register is available on the RESEERVE project's website (Inter- 
net 4). It consists of two parts: the West Balkan Mineral Register of Primary Raw Materials (Internet 5) and the West Balkan Mineral Register of Secondary Raw Materials (Internet 6).

Here we present work within the RESEERVE project to create the West Balkan Mineral Register of Primary Raw Materials (Internet 5) and in so doing, connecting the region to the European Minerals Intelligence Network.

\section{Materials and methods}

The aim of creating the West Balkan Mineral Register of primary raw materials is to address one of the major challenges presented in the Raw Materials Initiative (RMI) - II. Pillar: to foster the sustainable supply of raw materials from EU-based sources (European Commission, 2008). This effort should be facilitated and augmented by the mineral potential of the East and Southeast Europe (ESEE) region. Based on strong cooperation with representatives from the selected ESEE countries the following objectives can be established; (1) to identify relevant data providers and examine the quantity, quality, and format of data; (2) to examine existing datasets, extract publicly accessible data, and aggregate specific data when necessary; (3) to present a case study on the harmonisation of existing data with INSPIRE-compliant data (RESEERVE, 2017). The established West Balkan Mineral/Mining community and its Mineral Register should support an array of activities in the ESEE region, especially as a basis for further mineral exploration. These actions will contribute to the integration of the West Balkan region into the pan-European mineral market.

The objectives outlined herein are also aligned with the Europe 2020 Flagship Initiative on Resource Efficiency and the Roadmap to a Resource Efficient Europe (European Commission, 2011), as well as with the INSPIRE Directive establishing an infrastructure for spatial information (Directive 2007/2/EC). They also contribute to EU resource efficiency goals that are aligned with several UN Sustainable Development Goals (United Nations, 2015)

To start building a common raw material register it is essential to determine what data is needed to provide comprehensive information to local Knowledge Triangle Integration (KTI) stakeholders (from industry, education and research institutions) and the relevant authorities as well as to potential international investors. The best way to make information visible worldwide is to prepare in the way they can be available via the internet. Most EU countries (including Slovenia) are already part of the "pan-European Mineral Intelligence Network", whereas most of the SEE region still represents a gap. A first step towards a common register and consequently INSPIRE-aligned data was made with the defining of relevant attributes separated into two sub-tables - for primary and secondary raw materials. This paper focuses on primary raw materials data (Rokavec \& Draksler, 2020).

The work required to create common mineral resource datasets was divided into three steps:

1. Study of existing primary raw materials data

2. Selection of competent / relevant attributes

3 . Creating a common primary raw materials dataset.

Raw data required for the creation of the register was provided by the relevant responsible institutions from the West Balkan countries: Geological Survey of Slovenia (Slovenia), Croatian Geological Survey (Croatia), Geological Survey of Albania (Albania), Geological Survey of Montenegro (Montenegro), University of Belgrade - Faculty of Mining and Geology (Serbia), Geological Survey of the Federation of Bosnia and Herzegovina (Bosnia and Herzegovina), Macedonian Ecological Society (North Macedonia), and the Geological Survey of the Republic of Srpska (Bosnia and Herzegovina).

In order to study existing primary raw materials data, researchers from SEE national geological surveys captured, evaluated, harmonised, and provided national geologic data, including data on mineral resources, and managed the most relevant mineral datasets. Supplementary, educational and business partners contributed with their needs, experience, and knowledge related to potential investments in the exploitation of primary and secondary mineral resources (Draksler et al., 2018). Finally, the work of Task Partners (TPs), which participated in the project for a specific task, was of particular importance.

Comprehensive mineral data on metals, industrial minerals, and rocks were gathered at the national levels. Publicly accessible data was selected and gaps in existing mineral information were identified. Despite the fact that mineral commodities are in most countries property of the state, some data - such as resources and reserves at individual exploitation site in some countries is not publicly available. Publicly available data on mineral resources and their deposits are mainly published in mineral yearbooks, professional 
and scientific articles, expert magazines, websites etc. Datasets differ from country to country due to differences in mineral endowment, level of exploration, data details and the technical (IT) tools in use. Therefore, a comparison of datasets from different countries was performed, and the mineral data validated. A common dataset was established to ensure the comparability of the data provided. A broad set of mineral data from different sites has been included - from active, abandoned, and closed mines to sites where no previous mining activities have taken place, so called "greenfields" (Rokavec \& Draksler, 2020).

Construction of the Primary Raw Material (PRM) Register in West Balkan was performed in the following steps:

- Selection of relevant attributes describing raw materials and their deposit as good as possible.

- Comparison of selected attributes with INSPIRE terminology (upon Directive 2007/2/ $\mathrm{EC})$.

- Attributes and data mapping to INSPIRE.

- Creation of final common PRM Register.

Attributes selected for the PRM attribute table of datasets were taken from an analysis conducted according to the informational value for stakeholders. Some elementary statistics were compiled according to the Register's PRM attributes.

All attributes in the PRM table were divided as follows (Rokavec \& Draksler, 2020):

- Basic data, providing basic information on the deposit
- Technical data, related to technical descriptions of the deposit

- Geological data, describing the basic geology of the deposit

Further on, basic data is divided into:

- Name of mineral deposit

- Municipality of mineral deposit

- X and Y WGS84 (World Geodetic System) coordinates

Technical data is divided into:

- Current status of mine (abandoned/under maintenance/ operational)

- Mining method (open pit, underground)

- Concessionaire's name

- Mineral reserves (reported in tonnes).

Geological data is divided into:

- Basic geological map at scale 1:100.000

- Type of mineral deposit

- Size of mineral deposit

- Age of mineral deposit

- Host-rock type

- Major, minor, and trace minerals

- Final product made from the mineral.

\section{Results and discussion}

The analysis of primary raw material data resulted in 473 PRM sites described by 27 attributes, which were included into the West Balkan Mineral Register of Primary Raw Materials (Internet 5) and presented in an overview table (Fig. 2) and on a map (Fig. 3). Among the PRM sites, there are 248 metal sites and 225 sites of industrial minerals and construction materials. 56 sites or $12 \%$ of all sites are "greenfields".
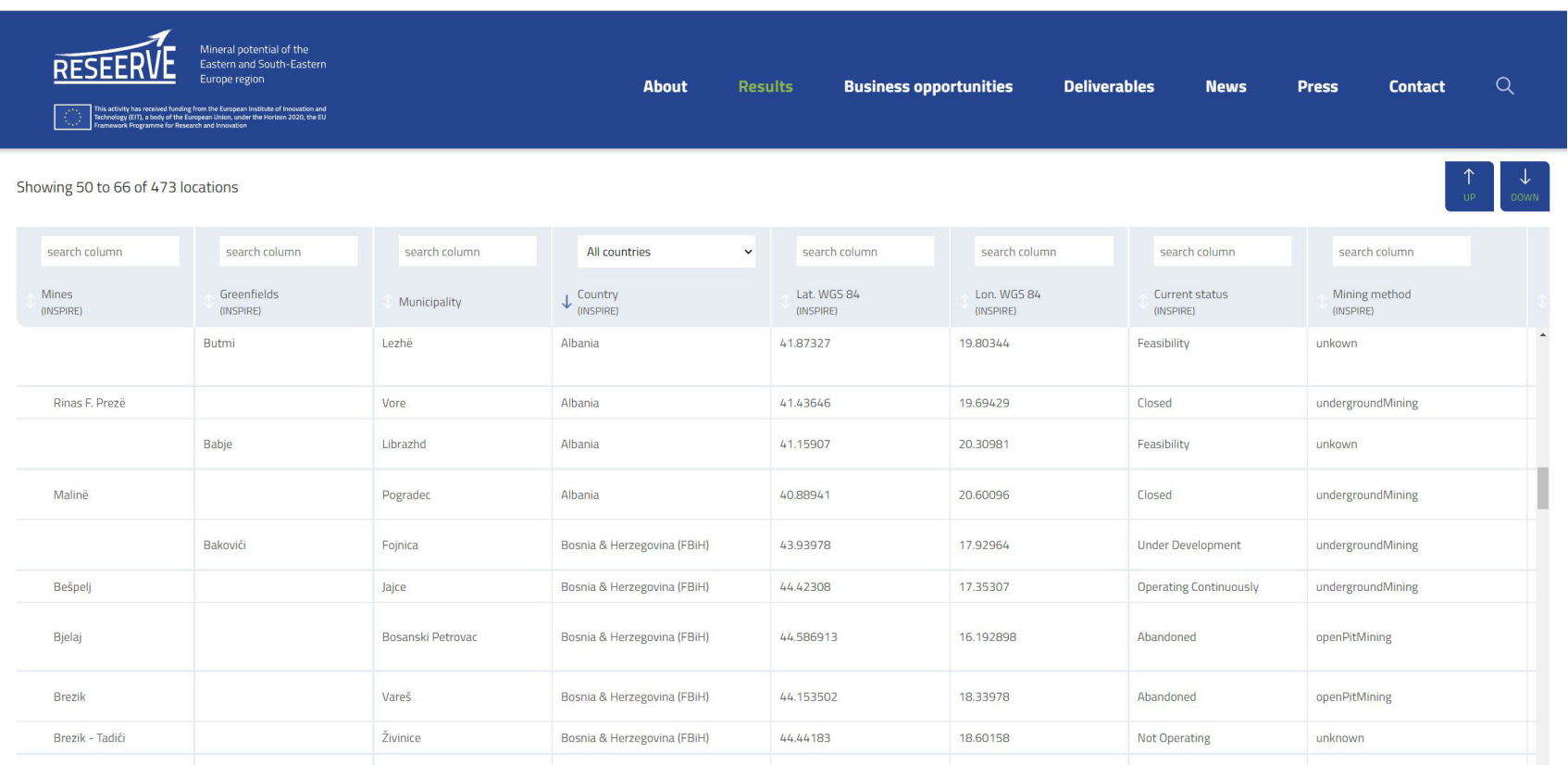

Fig. 2. A screen capture of overview table with 473 locations of primary raw materials, as part of the West Balkan Mineral Register of Primary Raw Materials (Internet 5). 


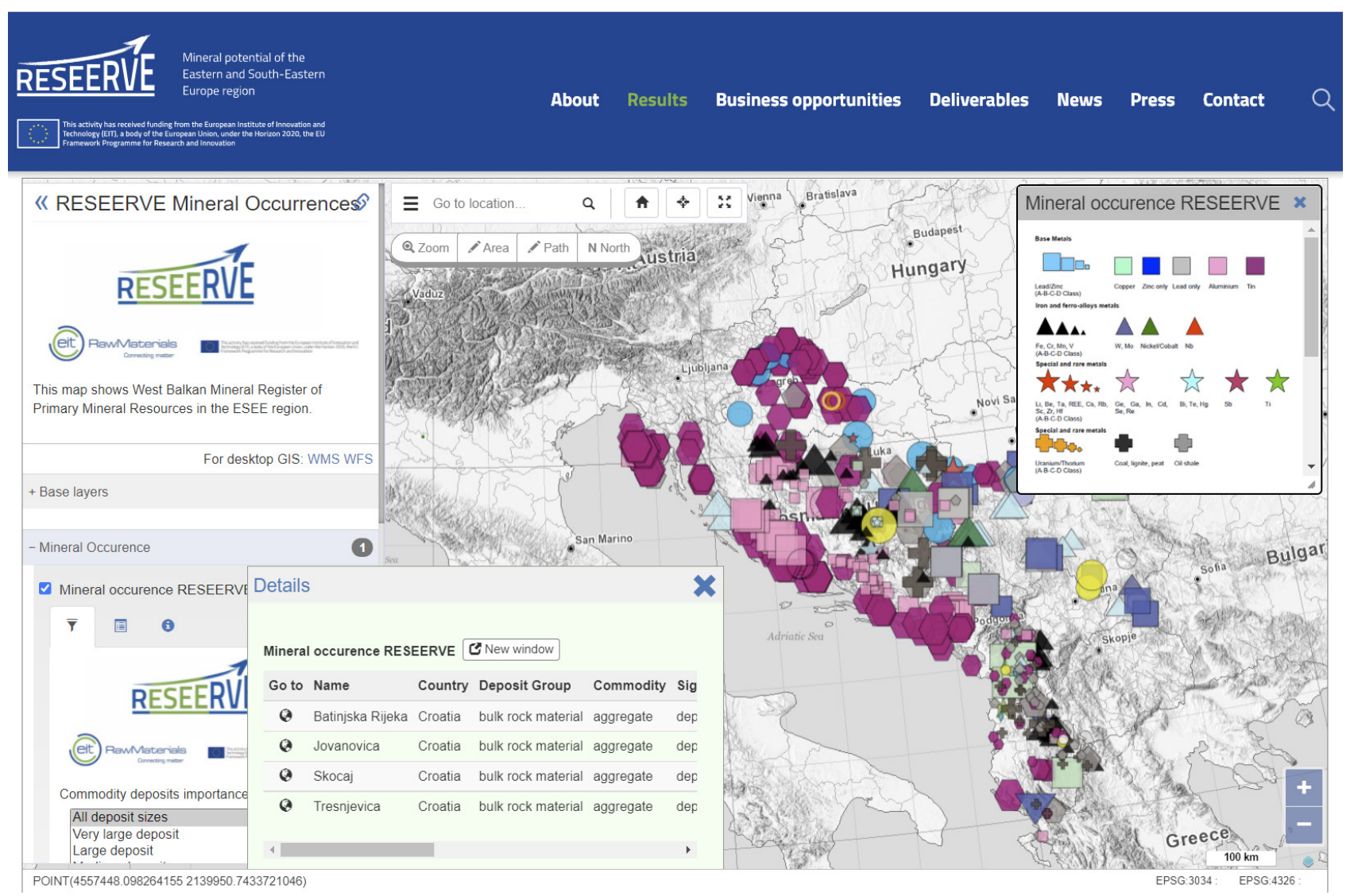

Fig. 3. A screen capture of EGDI map showing the locations of primary raw materials (PRM) with main data, as part of the West Balkan Mineral Register of Primary Raw Materials (Internet 5).

Various mining activities are performed on the remaining $88 \%$ of sites. The site's current status describes the phase of a site's "lifetime". Almost half of the selected sites are in operation. Socio-economic transitions and recent regional wars as well as a lack of proper legislation caused many mines to be abandoned. Very few sites have the status of closed mines, in cases where any closing procedure was applied. $9 \%$ of the selected sites are at the beginning of their "lifetime" cycle in terms of their feasibility status and pending approval.

Mining method is defined by referring to the type of mineral material mined, geological structure, and depth of the ore body. Open pit mining is/was the predominant extraction method at the selected sites, followed by underground mining, and quarrying, which is used for aggregates. In some cases, a combination of different mining methods is employed.

West Balkan PRM data mapped to INSPIRE has been harvested in the European Union Minerals Knowledge Data Platform (EU-MKDP) in the frame of the "Mintell4EU" project (Internet 7). The most interesting data of the sites are therefore visible also on the EGDI portal (Internet 8, Fig. 3). West Balkan mineral information is now accessible and easily shared across Europe and around the world (Rokavec \& Draksler, 2020).

\section{Mineral potential of West Balkan}

\section{Metal deposits related to the West Balkan Metallogenic Zones}

The greatest geotectonic unit of the West Balkan Peninsula are the Dinarides. They are divided into: the External Dinarides (along the Adriatic coast), and the Inner Dinarides (towards the Pannonian basin) (Fig. 4).

Several major mineral metallogenic provinces containing deposits of iron $(\mathrm{Fe})$, copper $(\mathrm{Cu})$, lead $(\mathrm{Pb})$ and zinc $(\mathrm{Zn})$ are known and described from the West Balkan area from West to East: the Dinaric, Vardar, Serbian-Macedonian, and the Carpatho-Balkan zone (Drovenik, 1984; Janković, 1990; Dimitrijević, 1997; Dill et al., 2008; Jelenković et al., 2008; Melcher \& Reichl, 2017; Rokavec \& Draksler, 2020).

1. The Dinaric Metallogenic Zone covers the western part of Central Serbia, most of BiH territory, southwest Croatia, coastal Montenegro, and part of Albania. Two metallogenic epochs the late Hercynian and the early Alpine - caused endogenic ore mineralisation. 

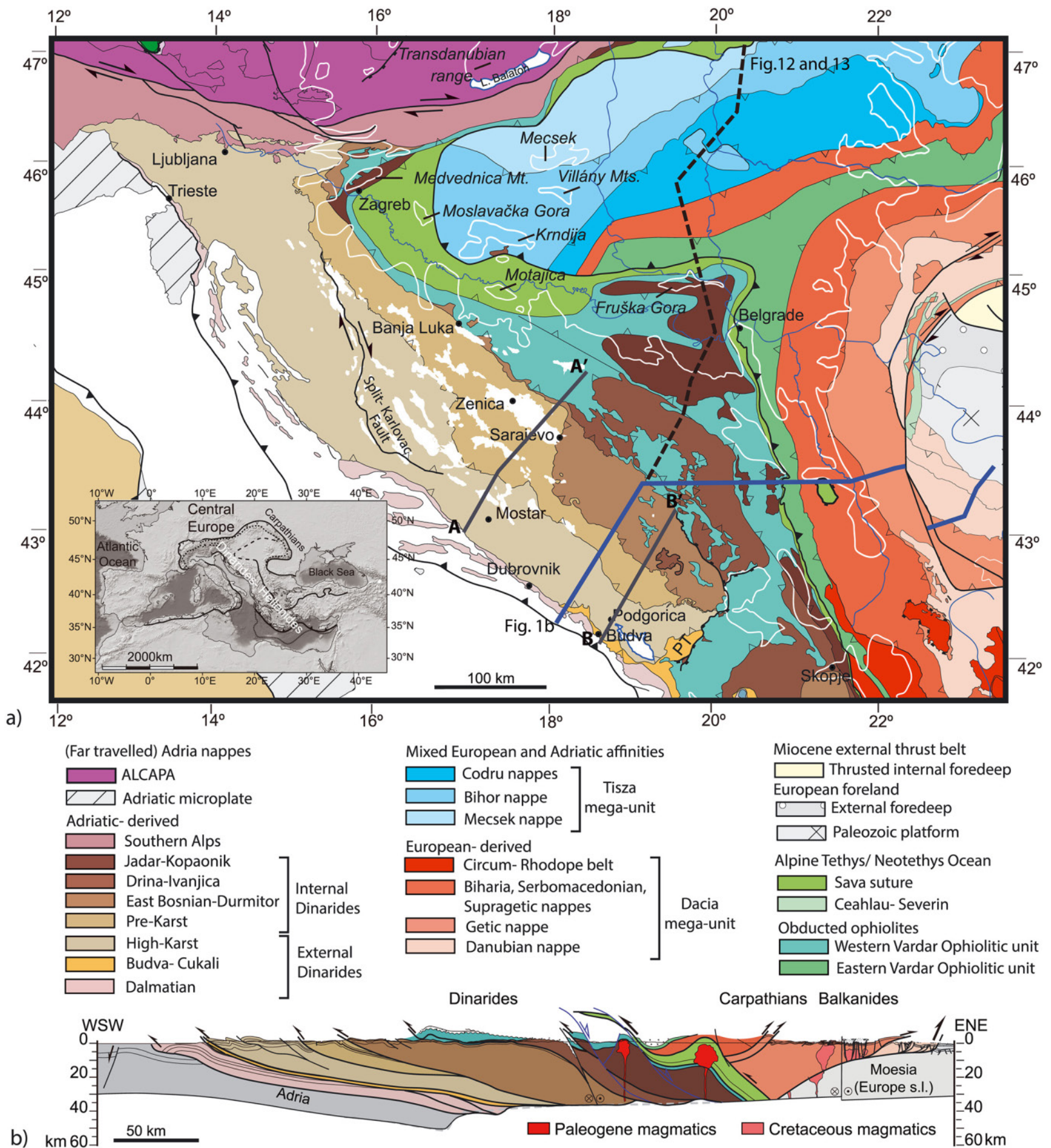

Fig. 4. Geotectonic units in the West Balkans (van Unen et al., 2019 where it was presented compiled and modified after many authors cited therein).

The Bosnia and Hercegovina Dinarides zone is well known for $\mathrm{Pb}-\mathrm{Zn}$ ores (Veovača, Olovo deposit (Palinkaš et al., 2016), Orti, Rupice (Operta \& Hyseni, 2016). While other metal ore deposits are present such as deposits of Fe (e. g. Radovan, Ljubija, Vareš-Smreka (Operta \& Hyseni, 2016)) and $\mathrm{Cu}$ ores (e. g. Mačkara (Jurković et al, 2010)), and even $\mathrm{Sb}$ ore occurs in the Čemernica district (Jurković et al., 1999). The Dinarides in western
Central Serbia represent the Zlatibor ore district bearing $\mathrm{Fe}$, while in the Priboj-Tutin Zone and the Polimlje ore district occur $\mathrm{Cu}$ deposits (Jelenković et al., 2008). Hydrothermal massive ores of $\mathrm{Fe}-\mathrm{Cr}-\mathrm{Ni}$ sulphides occur in basalts in Albania from the volcano-sedimentary formation of the Middle Triassic - Lower Jurassic ophiolites (Milushi et al, 2012) (Fig. 5). 
In the karstic External Dinarides, the most representative mineralisation consists in the form of Fe-bauxite deposits (Šinkovec et al., 1989, Palinkaš et al., 1993, Miko et al., 1999, Radusinović et al., 2017), which extend parallel to the Adriatic coast in Croatia and Montenegro.

2. The Vardar Zone is a belt that lies east of the Dinarides and west of the Serbo-Macedonian Massif. This zone consists of the Srem, Jadar, and Kopaonik blocks separated by ophiolitic fractures (Dimitrijević, 1997). The geological succession of the Vardar Zone consists of small blocks of crystalline schists, Carboniferous Veles Beds, Jurassic ultramafics, Triassic sediments, diabase-chert formations, Jurassic granitoids, Lower and Upper Cretaceous flysch, and Tertiary calc-alkaline volcano-intrusive complexes (Jelenković et al., 2008). The ophiolites of the Vardar Zone consist mainly of Mg-rich peridotite and dunite. Their metallogeny is characterized by major chromite and significant pyritic cupriferous deposits, as well as major magnesite and chrysotile asbestos deposits, locally nickel silicate, and nickeliferous iron deposits.

The Jurassic ophiolites complex (peridotite-pyroxene deposits bearing $\mathrm{Cr}, \mathrm{Ti}, \mathrm{Fe}$ ) constitute the main ore mineralisation in the Vardar zone Endogenous ore deposits related to these ophiolitic complexes are mostly $\mathrm{Ni}-\mathrm{Co}-\mathrm{Cu}-\mathrm{Fe}$ sulphides, pyritic cupriferous deposits, sporadically magnetite deposits, and minor gold mineralization, but without major chromite deposits (Janković, 1990; Dimitrijević, 1997; Jelenković et al., 2008).

Furthermore, after the previous authors, deposits of hydrothermal massive sulphides of Fe and
$\mathrm{Cu}$ (particularly important in Albanian basalts) are also present in the Vardar zone unit $\mathrm{Ni}-\mathrm{Cu}$ mineralisation could be found in Jurassic ultramafic units, as well as the $\mathrm{Cr}$ and Ti mineralisation generated during magmatic differentiation.

3. The Serbian-Macedonian Massif spreads North-South along the Great and South Morava valleys in Serbia into western North Macedonia and further into northern Greece (Antić et al., 2016). Metal deposits from the Oligocene-Miocene volcanic intrusive contain ores of $\mathrm{Pb}$ and $\mathrm{Zn}$, subordinated of $\mathrm{Cu}$ and $\mathrm{Sb}$, accompanied by $\mathrm{Au}, \mathrm{Ag}$, As, Ta, Bi and Fe. Hydro-thermal and metasomatic vein type ore deposits are present in the Kopaonik ore region, bearing $\mathrm{Pb}$ and $\mathrm{Zn}$ and other metals (Ag, Au). Additionally, a $\mathrm{Cu}$ porphyry type of deposit is also important in this belt (Fig. 6).

4. The Carpatho-Balkan Arc stretches through Eastern Serbia. The Serbian Carpathians in the northern part is an extension of the Carpathian Range and connects the western parts of the Balkan Mountains (Krstekanić et al., 2020).

Deposits in the Carpatho-Balkanian metallogenic province (eastern Serbian) are often associated with horst-graben structures. These were formed above the subducted oceanic lithosphere under the Eurasian plate and follow the Early Cretaceous closure of a Tethyan branch (Janković, 1990). The most important deposits ( $\mathrm{Cu}, \mathrm{Au}$, and rare $\mathrm{Pb}-\mathrm{Zn}$ ) are the porphyry copper, skarn type and volcano-hydrothermal (massive-sulphide): Bor deposit, Majdanpek deposit, Veliki Krivelj deposit (Bor metallogenic zone) (Drovenik, 1984) and Ridanj-Krepoljin Zone (Reškovica, Antina Čuka etc.) (Simić et al., 2019).

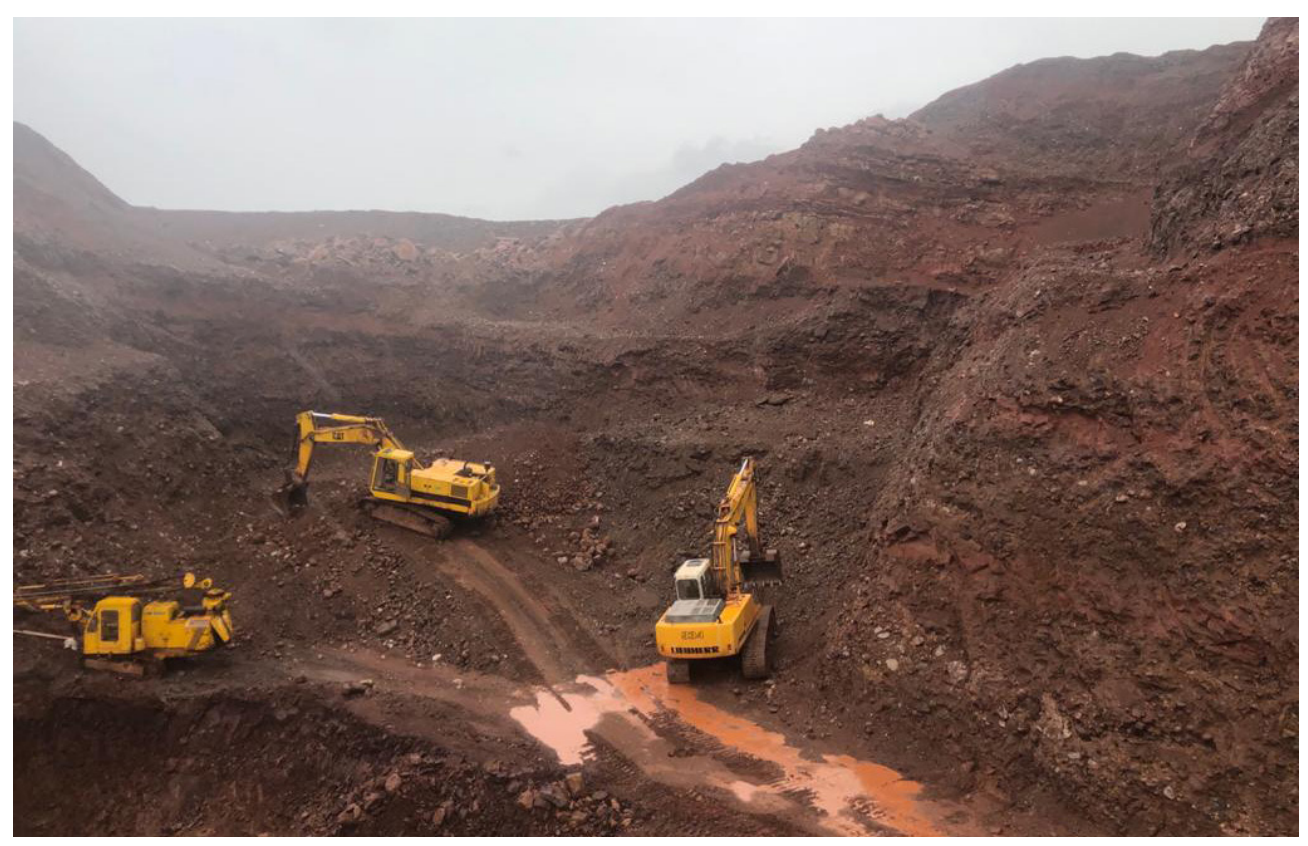

Fig. 5. Fe-Ni deposit in Albania (Photo: Archive of the Geological Survey of Albania). 


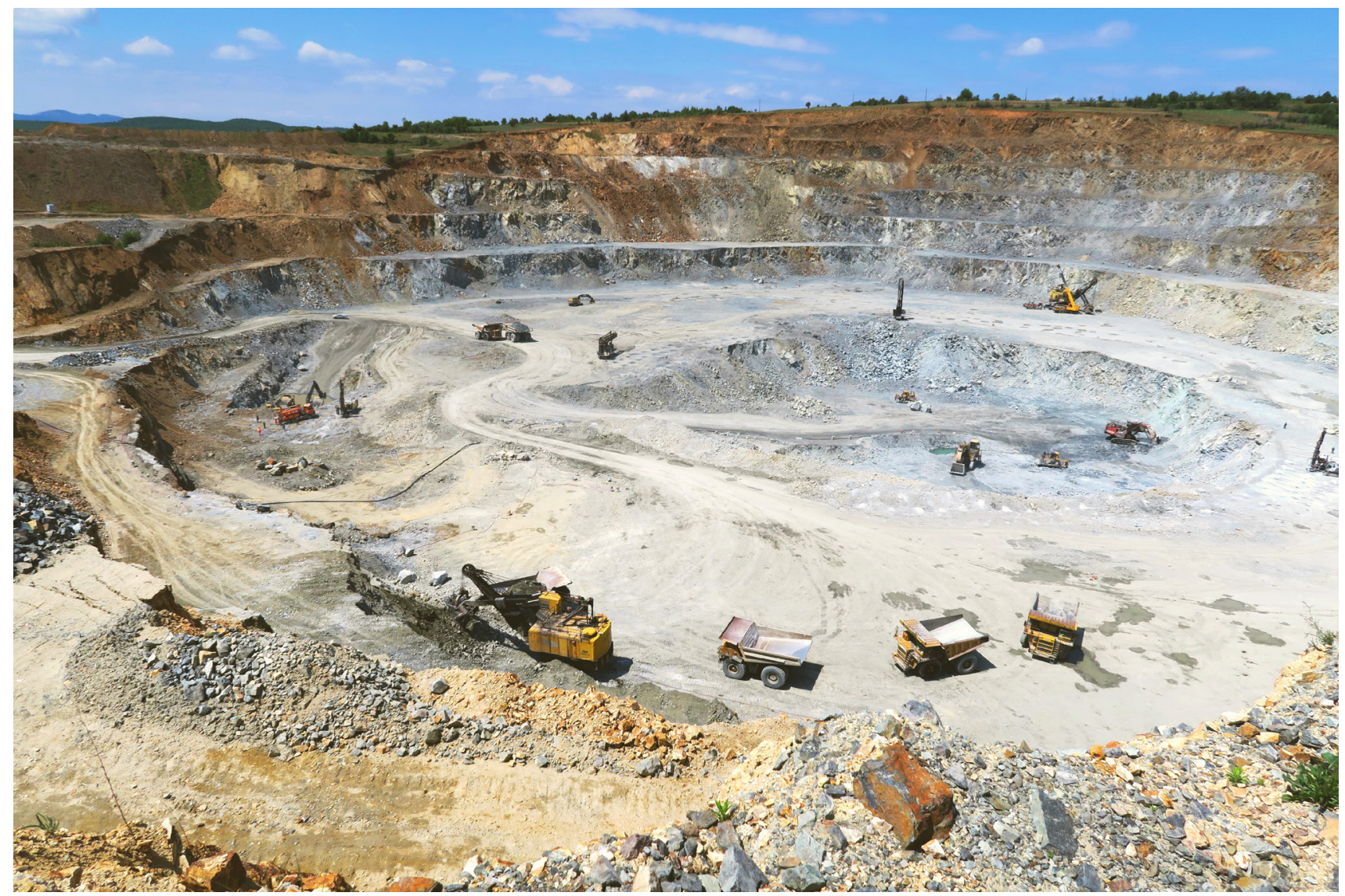

Fig. 6. Copper mine in North Macedonia (Photo: Archive of the Geological Survey of Slovenia).

\section{Industrial Minerals and Rocks (including some aggregates)}

The West Balkan region has an abundance of aggregates (crushed stones, sand and gravel), although these are only reported from Croatia and Montenegro in the register. Furthermore, bauxite is also abundant in carbonate host rocks throughout the Dinarides (Miko et al., 1999, Radusinović et al., 2017). The bauxite deposits in the register are reported from Croatia, Montenegro, $\mathrm{BiH}$ and Albania. In terms of industrial roc$\mathrm{ks}$, pure calcite is reported from all countries in the region, while magnesite deposits are reported from BIH and Serbia. Further, dimension stones and different types of clay are also present in the region (Spasovski \& Spasovski, 2012; Stolić, 2016; Hajdarević \& Babajić, 2018)

\section{Critical Raw Materials}

A list of critical raw materials (CRMs) for the EU has been defined by the European Commission (2020). These raw materials are of high importance to the EU economy and their supply is associated with high risk. The most commonly reported CRMs in the West Balkan region are minerals of bauxite, magnesium (Mg), antimony $(\mathrm{Sb})$, and titanium $(\mathrm{Ti})$.

\section{Raw Materials for Electric Vehicle Batteries}

Aligned with EU policies and initiatives are relevant regarding battery raw materials $(\mathrm{Ba}-$ tteries Directive (2006/66/EC), Strategic Action Plan on Batteries (COM(2019) 176 final), European Battery Alliance (Internet 9), etc.)the register also contains mineral deposits with raw materials used in electric vehicle batteries. All primary minerals for batteries are found in the West Balkan region, except graphite. By providing these raw materials to EU producers of e-vehicle components, the West Balkan represents a great source of support for the EU's transformation into a pro-e-mobility region, and consequently a greener and more sustainable society. There is a high potential for the supply of raw materials to the battery industry in this region.

\section{Conclusion}

The European Union aims to become less dependent on imported minerals from other continents. The West Balkan region is recognized by the European Commission as one of the most outstanding potential sources of mineral raw materials.

The Geological Survey of Slovenia, with support from its local partners, took tangible steps in filling the gap in the existing mineral 
information network through the EIT RM projects. Bringing the West Balkan region into the EU raw materials market also represents another of the project's benefits.

The West Balkan Mineral Register has been created within the RESEERVE project. The mineral data are included in the European information network and thus became publicly accessible and attractive for potential investments in the mineral sector in West Balkans. The Mineral Register provides basic information to reinforce national mineral management and make Europe more mineral self-sufficient, which in turn is crucial for European industry. Data summarized in the Mineral Register will increase the visibility of the most promising mineral sites in the West Balkan region and will serve to increase investments in exploration and potential extraction there. The resulting positive long-term effects will consist in increased innovation in the West Balkan region, the transfer of new technologies, job creation, and will help stem brain-drain in the region.

The complete West Balkan Mineral Register is freely available on the RESEERVE project's website: https://reseerve.eu/results.

\section{Acknowledgements}

The authors would like to thank the reviewers and experts from EIT RawMaterial to streamline their work. Our thanks go also to the paper reviewers for their valuable comments and constructive suggestions.

This paper summarises the results of the RESEERVE project, funded by the European Institute of Innovation and Technology (EIT).

\section{References}

Antić, M., Peytcheva, I., von Quadt, A., Kounov, A., Trivić, B., Serafimovski T., Tasev, G., Gerdjikov, I. \& Wetzel, A. 2016: Pre-Alpine evolution of a segment of the North-Gondwanan margin: Geochronological and geochemical evidence from the central Serbo-Macedonian Massif. Gondwana Research, 36: 523-544. http://dx.doi.org/10.1016/j.gr.2015.07.020 1342-937X

Batteries Directive 2006/66/EC. Directive 2006/66/EC of the European Parliament and of the Council of 6 September 2006 on batteries and accumulators and waste batteries and accumulators and repealing Directive 91/157/EEC. Internet: https://eur-lex.europa.eu/legal-content/
$\mathrm{EN} / \mathrm{TXT} / \mathrm{PDF} /$ ?uri=CELEX:02006L 0066 20131230\&rid $=1$ (5. 5. 2021)

Dill, H.G., Sachsenhofer, R.F., Grecula, P., Sasvári, T., Palinkaš, L.A., BorojevićŠoštarić, S., Strmić-Palinkaš, S., Prochaska, W., Garuti, G., Zaccarini, F., Arbouille, D. \& Schulz, H-M. 2008: Fossil fuels, ore and industrial minerals. In: McCann, T. (ed.): The Geology of Central Europe, 2: Mesozoic and Cenozoic. The Geological Society London: 1341-1449.

Dimitrijević, M. D. 1997: Geology of Yugoslavia. Geological Institute - GEMINI, Belgrade, Spec. Publ., Monograph: 197 p.

Directive 2007/2/EC. Directive 2007/2/EC of the European Parliament and of the Council of 14 March 2007 establishing an Infrastructure for Spatial Information in the European Community (INSPIRE). Official Journal of the European Union 108. Internet: https:// eur-lex.europa.eu/legal-content/EN/TXT/ PDF/?uri=CELEX:32007L0002\&from $=$ EN (21.01.2021)

Draksler, M., Rokavec, D., Šolc, U. \& Zajc Benda, T. 2018: RawMaterials "RESEERVE" project - mineral potential of the SEE region. In: Vujić, S., Radosavljević, M., Polavder, S. \& Maksimović, S. (eds.): Mining and Geology Today, Proceedings of the II International Symposium, Mining Institute Belgrade, Balkan Academy of Mining Sciences, Academy of Engineering Sciences of Serbia, Belgrade: $294 \mathrm{p}$.

Drovenik, M. 1984. Nahajališča mineralnih surovin. Fakulteta za naravoslovje in tehnologijo, Ljubljana: $375 \mathrm{p}$.

European Commission, 2008: The raw materials initiative - Meeting our critical needs for growth and jobs in Europe. Communication from the Commission to the Council and the European Parliament. COM(2008) 699 final (4 November 2008), Brussels. Internet: https:// eur-lex.europa.eu/LexUriServ/LexUriServ. do?uri=COM:2008:0699:FIN:EN:PDF (13. 1. 2021)

European Commission, 2011: Roadmap to a Resource Efficient Europe. Communication from the Commission to the European Parliament, the Council, the European Economic and Social Committee and to Committee of the Regions: $\operatorname{COM}(2011) 571$ final (20September 2011), Brussels. Internet:https:// eur-lex.europa.eu/legal-content/EN/TXT/ $\mathrm{PDF} /$ ?uri=CELEX:52011DC0571\&from $=\mathrm{EN}$ (13. 1. 2021) 
European Commission, 2020: Critical Raw Materials Resilience: Charting a Path towards greater Security and Sustainability. Communication from the Commission to the European. Parliament, the Council, the European Economic and Social Committee and the Committee of the Regions. COM(2020) 474 final (30 September 2020), Brussels. Internet: https://eur-lex.europa.eu/legal-content/EN/TXT/ $\mathrm{PDF} /$ ?uri=CELEX:52020DC0474\&from $=\mathrm{EN}$ (13. 1. 2021)

Hajdarević, I. \& Babajić, E. 2018: Dimension stone of Bosnia. e_collection of the Faculty of Civil Engineering Mostar, 8, Special Edition: 65-86.

Janković, S. 1990: The ore deposits of Serbia: Regional metallogenic settings, environments of deposition and types. Faculty of Mining and Geology, Belgrade: 760 p.

Jelenković, R., Kostić, A., Životić, D. \& Ercegovac, M. 2008: Mineral resources of Serbia, Geologica Carpathica, 59/4: 345-361. Internet: http://www.geologicacarpathica. com/browse-journal/volumes/59-4/article-451/ (4. 2. 2021)

Jurković, I., Ramović, M. \& Zec, F. 1999: Chemical and geochemical characteristics of the Čemernica antimonite deposit in the mid-Bosnian schist mountains. Rudarsko-geloškonaftni zbornik, 11: 1-16.

Jurković, I., Garašić, V. \& Hrvatović, H. 2010: Geochemical characteristics of barite occurrences in the Palaeozoic complex of Southeastern Bosnia and their relationship to the barite deposits of the Mid-Bosnian Schist Mountains. Geologia Croatica, 63/2: 241-258. https://doi.org/10.4154/gc.2010.20

Krstekanić, N., Matenco, L., Toljić, M., Mandic, O., Stojadinovic, U. \& Willingshofer, E. 2020: Understanding partitioning of deformation in highly arcuate orogenic systems: Inferences from the evolution of the Serbian Carpathians, Global and Planetary Change, 195. https:// doi.org/10.1016/j.gloplacha.2020.103361.

Miko, S., Durn, G. \& Prohić, E. 1999: Evaluation of terra rossa geochemical baselines from Croatian karst regions, Journal of Geochemical Exploration, 66/1-2: 173-182. https://doi.org/10.1016/S0375-6742(99)00010-2

Milushi, I., Hoxha, V., Kodra, A. \& Gjeçi, K. 2012. Volcanic Massive Sulphide (VMS) Deposits of the Middle Triassic - Lower Jurassic Ophiolite of Albania. J. Int. Environmental Application \& Science, 7/3: 493-502.
Melcher, F. \& Reich, C. 2017: Economic Geology of the Eastern and South-eastern European (ESEE) Region. Berg Huettenmaenn Monatsh, 162: 238-244. https://doi.org/10.1007/ s00501-017-0625-4.

Operta, M. \& Hyseni, S. 2016: Mineral Resources Metallogenic Zone BorovicaVares-Cevljanovici (BiH). Interna-tional journal of technology enhancements and emerging engineering research, 4/2: 16-20. Internet: https://www.researchgate.net/publication/316317628_Mineral_Resources_ Metallogenic_Zone_Borovica-VaresCevljanovici_Bih (5. 5. 2021)

Palinkaš, L., Miko, S., Dragičević, I., Namjesnik, K. \& Papeš, J. 1993: Geochemical Exploration for Blind Bauxite Ore Bodies in Jajce, Central Bosnia. Acta Geologica Hungarica, 36/4: 459-477.

Palinkaš, L. A., Damyanov, Z. K., Borojević Šoštarić, S., Strmić Palinkaš, S. \& Marinova, I. 2016: Divergent drift of Adriatic-Dinaridic and Moesian carbonate platforms during the rifting phase witnessed by triassic MVT $\mathrm{Pb}-\mathrm{Zn}$ and SEDEX deposits; a metallogenic approach. Geologia Croatica, 69/1: 75-79. https://doi.org/10.4154/GC.2016.06

Radusinović, S., Jelenković, R., Pačevski, A., Simić, V., Božović, D., Holclajtner-Antunović, I. \& Životić D. 2017: Content and mode of occurrences of rare earth elements in the Zagrad karstic bauxite deposit (Nikšić area, Montenegro). Ore Geology Reviews, 80: 406-428. https://doi.org/10.1016/j. oregeorev.2016.05.026

RESEERVE, 2017: RESEERVE. Mineral potential of the ESEE region. Project proposal, EIT RawMaterials: $35 \mathrm{p}$.

Rokavec, D., Draksler, M., Šolc, U. \& Miletić, S. 2018: Mineralni potencial Jugovzhodne Evrope - projekt RESEERVE. Mineral, 58/4: 20-21. Internet: https://www.mineral-revija. si/1993/Mineralni-potencial-JugovzhodneEvrope-projekt-RESEERVE (27. 12. 2020)

Rokavec, D. \& Draksler, M. 2020: Report on creating West Balkan Mineral Register of PMR data (D4.3.). (Version 1.0., Report) Geological Survey of Slovenia, Ljubljana: $13 \mathrm{p}$. Internet: https://reseerve.eu/upload/content/90/ d4-3-reseerve_report-west-balkan-mineral-register-of-prm-data.pdf (7. 1. 2021)

Simić, V., Jelenković, R. \& Životić, D. 2019: Mineral Resources of Serbia: Environmental, Societal and Economic Challenges. In: Janev, I. (ed.): Serbia: Current Issues and Challenges in the 
Areas of Natural Resources, Agriculture and Environment, 1-56.

Spasovski, O. \& Spasovski, D. 2012: The potential of the nonmetallic mineral resources in the Republic of Macedonia. Zbornik na trudovi, 91-94. Internet: https://eprints.ugd. edu.mk/2187/1/Zbornik_na_Trudovi_2012_ CD\%281\%29.PDF (2.2.2021)

Stolić, N. 2016: Status and further development of basic geological exploration in the Republic of Macedonia. Special edition of Geologica Macedonia, No.4. Macedonian Geological Society, Struga, Proceedings of the Third Congress of Geologists of the Republic of Macedonia, Book 1: 23-31.

Šinkovec, B., Sakač, K., Palinkaš, L. \& Miko, S. 1989: Geology of bauxite deposits in the Lištica (Herzegovina) and Imotski (Dalmatia) regions. ICSOBA Travaux, 19/2: 459-477.

United Nations, 2015: Transforming our world: the 2030 Agenda for Sustainable Development. A/RES/70/1. Internet: https://sdgs.un.org/sites/default/files/publications/21252030\%20 A genda $\% 20$ for $\% 20$ Susta inable $\% 20$ Development\%20web.pdf (1.2.2021)

van Unen, M., Matenco, L., Nader, F. H., Darnault, R., Mandic, O. \& Demir, V. 2019: Kinematics of foreland-vergent crustal accretion: Inferences from the Dinarides evolution. Tectonics, 38: 49-76. https://doi.org/10.1029/2018TC005066

Internet sources:

Internet 1: EIT's Knowledge and Innovation Communities: https://eit.europa.eu/our-communities/eit-innovation-communities (20. 2. 2021)
Internet 2: Project RESEERVE website. https:// reseerve.eu/ (5. 1. 2021)

Internet 3: Mining/Mineral Support Services (MineService). https://eitrawmaterials.eu/ project/mineservice/ (13. 1. 2021)

Internet 4: West Balkan Mineral Register. https:// reseerve.eu/results (5. 1. 2021)

Internet 5: West Balkan Mineral Register of Primary Raw Materials. https://reseerve.eu/ results/west-balkan-mineral-register-of-primary-raw-materials (5. 1. 2021)

Internet 6: West Balkan Mineral Register of Secondary Raw Materials. https://reseerve. $\mathrm{eu} / \mathrm{results} /$ west-balkan-mineral-register-of-secondary-raw-materials (5. 1. 2021)

Internet 7: Mineral Intelligence for Europe (Mintell4EU). https://geoera.eu/projects/ mintell4eu7/ (13. 1. 2021)

Internet 8: EuroGeoSurveys' European Geological Data Infrastructure (EGDI). http://www.europe-geology.eu/map-viewer/ (5. 1. 2021)

Internet 9: European Battery Alliance. https:// ec.europa.eu/growth/industry/policy/european-battery-alliance_en (5. 5. 2021)

Internet 10: Strategic Plan on Batteries (report) TEN/696. Report from the Commission to the European Parliament, the Council, the European Economic and Social Committee, the Committee of the Regions and the European Investment Bank on the Implementation of the Strategic Action Plan on Batteries: Building a Strategic Battery Value Chain in Europe. Internet: https:// www.eesc.europa.eu/en/our-work/opinions-information-reports/opinions/strategic-action-plan-batteries-report (5. 5. 2021) 